\title{
Penggunaan Arang Aktif, Arang Tongkol Jagung, PGPR dan Cairan Rumen Sapi pada Proses Pra Pengomposan Kertas Bekas Bertinta
}

\author{
Annisa Rahmawati ${ }^{1 *}$, Hesti Kurniahu ${ }^{1}$, dan Sriwulan ${ }^{1}$. \\ ${ }^{1,1,1}$ Prodi Biologi FMIPA Universitas PGRI Ronggolawe Tuban \\ "E-mail: annisasigit @gmail.com
}

\begin{abstract}
Abstrak: Proses pengomposan kertas bekas bertinta dapat dilakukan karena kertas bekas bertinta memiliki kandungan materi organik berupa selulosa, hemiselulosa, lignin dan senyawa abu. Namun tidak seperti bahan organik lainnya kertas bekas bertinta telah mengalami berbagai proses kimia dalam pembuatannya sehingga perlu dilakukan perlakuan perendaman terlebih dahulu untuk menurunkan kandungan berbagai bahan kimia. Dalam hal ini kertas bekas bertinta direndam dengan aquades yang ditambahkan dengan arang aktif, arang tongkol jagung, PGPR dan cairan rumen sapi. PGPR ini selanjutnya ditambahkan buffer fosfat $\mathrm{pH} 7$ dan diinkubasi selama 7 hari pada suhu ruang tanpa terkena cahaya matahari. Cairan rumen sapi diambil di RPH Jenu di Kabupaten Tuban, cairan ini diambil langsung setelah sapi dipotong dan dimasukkan kedalam termos selanjutnya ditambahkan buffer fosfat $\mathrm{pH} 7$ dan diinkubasi selama 7 hari pada suhu ruang dan tidak terkena cahaya matahari. Pemberian arang aktif, arang tongkol jagung dan PGPR dapat dilakukan pada proses pra pengomposan kertas bekas bertinta dengan starter cairan rumen sapi tanpa menyebabkan terjadinya fluktuasi $\mathrm{pH}$ dan suhu
\end{abstract}

\section{Kata Kunci: Arang Aktif, Arang Tongkol Jagung, Pgpr, Cairan Rumen, Kertas Bekas}

\begin{abstract}
The process of composting inked waste paper can be done because inked waste paper contains organic material in the form of cellulose, hemicellulose, lignin and ash compounds. But unlike other organic materials inked used paper has undergone various chemical processes in its manufacture so it needs to be done soaking treatment in advance to reduce the content of various chemicals. In this case inked scrap paper is soaked with distilled water added with activated charcoal, corn cobs charcoal, PGPR and rumen liquid. The PGPR was then added to a phosphate buffer of $\mathrm{pH} 7$ and incubated for 7 days at room temperature without exposure to sunlight. Rumen fluid is taken at the Jenu Slaughterhouse in Tuban Regency, this liquid is taken directly after the cow is slaughtered and put into a flask then phosphate buffer $\mathrm{pH} 7$ is added and incubated for 7 days at room temperature and not exposed to sunlight. Provision of activated charcoal, corn cobs charcoal and PGPR can be done in the process of pre-
\end{abstract}


composting inked waste paper with a cow rumen liquid starter without causing $\mathrm{pH}$ and temperature fluctuations.

\section{Keywords: Activated Charcoal, Corncob Charcoal, Pgpr, Rumen Liquid, Waste Paper}

Kertas bekas bertinta merupakan salaha satu jenis limbah organik yang telah banyak mengalami proses kimia dalam pembuatan dan pemanfaatannya. Kertas terbuat dari bahan baku berupa serat dari kayu. Sehingga kertas memiliki komposisi organik berupa $85 \%$ selulosa, $8 \%$ hemiselulosa, $5 \%$ lignin dan sisanya berupa senyawa abu. Proses kimia dalam produksi kertas menyebabkan kertas mengandung bahan pemutih, chlorine dan lain-lain. Penggunaan kertas sebagai alat untuk mencetak data juga menyebabkan penambahan logam timbal $(\mathrm{Pb})$ dalam kertas (Hermawan dan Yulis, 2014).

Kertas digunakan sebagai pencetak data biasanya hanya sekali pakai sehingga menjadi limbah. Penanganan limbah kertas bertinta pada umumnya cenderung sembarangan dan menyalahi aturan serta membahayakan kesehatan dan lingkungan misalnya sebagai pembungkus makanan, dibakar, atau dibuang langsung tanpa proses pengolahan terlebih dahulu. Padahal dalam kertas bekas bertinta mengandung berbagai bahan kimia berbahaya salah satunya logam berat $\mathrm{Pb}$ yang dapat masuk ke rantai makanan sehingga menyebabkan gangguan kesehatan bahkan mengancam kematian manusia dan hewan (Ahmad dan Saftyaningsih, 2014; Hardiani, dkk., 2011; Wardalia, 2016).

Kandungan organik berupa lignin, selulosa dan hemiselulosa pada kertas pada dasarnya dapat didegradasi menjadi komponen yang lebih sederhana yaitu $\mathrm{N}, \mathrm{K}, \mathrm{C}, \mathrm{P}_{2} \mathrm{O}_{5}$, $\mathrm{K}_{2} \mathrm{O}, \mathrm{CaO}, \mathrm{MgO}$, dan $\mathrm{Mn}$. Unsur-unsur tersebut dapat dimanfaatkan oleh tanaman pada proses pertumbuhannya. Proses degradasi ini melibatkan bakteri selulolitik yang dapat menguraikan materi organik yang terkandung dalam kertas yaitu selulosa, hemiselulosa dan lignin. Proses ini dapat dipercepat dengan melakukan pengomposan melalui penambahan cairan rumen sapi yang didalamnya terdapat kelompok bakteri selulolitik. Bakteri selulolitik pada cairan rumen sapi berfungsi untuk membantu mencerna selulosa, hemiselulosa dan lignin pada pakan sapi berupa rumput-rumputan (Hermawan, et al, 1999 dalam Kasli, 2008; Hermawan dan Yulis, 2014; Rahmawati, dkk., 2017).

Namun adanya berbagai kandungan kimia yang terdapat dalam bahan baku kompos yaitu kertas bekas bertinta dapat menyebabkan proses pengomposan tidak berjalan optimal (Rahmawati, dkk., 2017). Untuk itu perlu dilakukan perlakuan pra pengomposan dengan cara menambahkan beberapa bahan (arang aktif, arang tongkol jagung, PGPR dari berbagai akar tanaman dan tanah disekitar perakaran tanaman alangalang (Imperata cylindrical), gletang (Tridax procumbens), paku-pakuan (Pteris sp.), jagung (Zea mays), Waltheria indica serta cairan rumen sapi) yang berpotensi sebagai penurun bahan kimia dalam kertas bekas bertinta tanpa merusak tekstur bahan kompos 
yaitu kertas bekas bertinta. Pada tulisan ini akan dibahas metode aplikasi arang aktif, arang tongkol jagung, PGPR dan bakteri rumen sapi dan potensinya sebagai agen pendegradasi bahan kimia pada limbah kertas bertinta sehingga proses pengomposan berjalan optimal.

\section{METODE PENELITIAN}

Penelitian ini menggunakan alat berupa gunting kertas, tungku pembakaran, cetok, timbangan digital, bak plastik, jirigen,botol plastik, termos air, gelas ukur, cutter, toples, dan $\mathrm{pH}$ meter merk ituin. Selain itu penelitian ini juga menggunakan bahan berupa kertas bekas bertinta, aquades, arang aktif dengan merk dagang norit, tongkol jagung, cairan rumen sapi, akar dan tanah disekitar perakaran tanaman alang-alang (Imperata cylindrical), gletang (Tridax procumbens), paku-pakuan (Pteris sp.), jagung (Zea mays) dan Waltheria indica serta buffer fosfat $0.01 \mathrm{M} \mathrm{pH} 7$.

\section{Tahap Pra Pelaksanaan}

Arang aktif yang digunakan dalam penelitian ini adalah arang aktif yang sudah beredar di pasaran dengan merk dagang "norit". Sementara untuk arang tongkol jagung didapatkan dengan cara membakar tongkol jagung tua yang telah dikeringkan dibawah sinar matahari untuk mengurangi kadar air pada tungku pembakaran sampai menjadi arang (Saputra, dkk. 2019). Sedangkan PGPR diperoleh dengan cara mengambil lima akar dan tanah sekitar akar 5 tanaman yaitu alang-alang (Imperata cylindrical), gletang (Tridax procumbens), paku-pakuan (Pteris sp.), jagung (Zea mays) dan Waltheria indica masing-masing seberat $50 \mathrm{~g}$ yang dilanjutkan dengan melakukan maserasi dengan mortar dan pestle, setelah itu ditambakan buffer fosfat $\mathrm{pH} 7$ sebanyak $125 \mathrm{ml}$ kemudian dimasukkan ke dalam wadah tertutup dan diinkubasi pada suhu ruang serta tidak terkena cahaya matahari langsung selama 7 hari. Penambahan buffer fosfat $\mathrm{pH} 7$ juga dilakukan pada cairan rumen sapi yang diambil langsung di rumah potong hewan daerah Jenu Tuban pada pukul 02.00 WIB. Sebelumnya buffer fosfat $\mathrm{pH} 7$ dimasukkan ke dalam termos air selanjutnya baru ditambahkan cairan rumen sapi yang baru diambil kemudian ditutup dan diinkubasi selama 7 hari (Aditiya, 2014).

\section{Tahap Pelaksanaan}

Tahap pelaksanaan diawali dengan memotong kecil-kecil kertas bekas bertinta yang selanjutnya ditambahkan aquades sampai basah tetapi tidak sampai menetes. Kemudian ditimbang dan dimasukkan kedalam 25 toples kecil masing-masing seberat 100 g. Selanjutnya ditambahkan agen penurun bahan kimia pada kertas yaitu arang aktif dengan merk dagang norit sebanyak $825 \mathrm{mg}$ ke dalam $100 \mathrm{~g}$ kertas bekas bertinta yang telah ditambahkan aquades sebelumnya, arang tongkol jagung seberat $875 \mathrm{mg}$ ke dalam $100 \mathrm{~g}$ kertas bekas bertinta basah, PGPR yang telah dinkubasi selama seminggu sebanyak $10 \mathrm{ml}$ ke dalam $100 \mathrm{~g}$ kertas bekas bertinta yang dibasahi, dan $10 \mathrm{ml}$ cairan rumen sapi yang diinkubasi menggunakan buffer fosfat $\mathrm{pH} 7$ dicampurkan ke dalam kertas bekas 
bertinta basah seberat $100 \mathrm{~g}$. Sementara untuk kontrol $100 \mathrm{~g}$ kertas bekas bertinta basah ditambahkan $10 \mathrm{ml}$ aquades. Kemudian toples ditutup rapat dan diletakkan pada ruangan yang tidak terkena cahaya matahari secara langsung pada suhu ruang. Dibiarkan selama satu minggu dengan melakukan pengukuran $\mathrm{pH}$ dan suhu setiap harinya.

\section{Tahap Analisis Data}

Data yang diperoleh berupa suhu dan $\mathrm{pH}$ selama perlakuan kemudian dianalisis menggunakan uji Manova pada system perhitungan statistic SPSS 24. Nilai signifikansi yang digunakan yaitu 0.05

\section{HASIL DAN PEMBAHASAN}

Hasil pengamatan selama 7 hari penelitian yang dilakukan pada pra pengomposan dengan mencampurkan arang aktif, arang tongkol jagung, PGPR dan cairan rumen sapi adalah sebagai berikut:

Tabel 1. Rerata pH kertas pasca perlakuan agen penurun bahan kimia pra pengomposan

\begin{tabular}{lllllllll}
\hline No & \multicolumn{1}{c}{ Perlakuan } & 1 & 2 & 3 & 4 & 5 & 6 & 7 \\
\cline { 3 - 8 } & & 7 & 7 & 7 & 7 & 7 & 7 & 7 \\
\hline 1. & Kontrol & 7 & 7 & 7 & 7 & 7 & 7 & 7 \\
2. & Arang aktif & 7 & 7 & 7 & 7 & 7 & 7 & 7 \\
3. & Arang tongkol jagung & 7 & 7 & 7 & 7 & 7 & 7 & 7 \\
4. & PGPR & 7 & 7 & 7 & 7 & 7 & 7 & 7 \\
$\mathbf{5 .}$ & Cairan rumen sapi & 7 & & & & & \\
\hline
\end{tabular}

Tabel 2. Rerata suhu $\left({ }^{\circ} \mathrm{C}\right)$ kertas pasca perlakuan agen penurun bahan kimia pra pengomposan

\begin{tabular}{llccccccc}
\hline No & \multicolumn{1}{c}{ Perlakuan } & \multicolumn{7}{c}{ Hari ke- } \\
\cline { 3 - 8 } & & 1 & 2 & 3 & 4 & 5 & 6 & 7 \\
\hline 1. & Kontrol & 28.8 & 29 & 27.6 & 30 & 27.8 & 29.4 & 29 \\
2. & Arang aktif & 30 & 30 & 28.8 & 30 & 29 & 28.8 & 29 \\
3. & Arang tongkol jagung & 30 & 30 & 29 & 30 & 29 & 29 & 29 \\
4. & PGPR & 30 & 30 & 29 & 29 & 29 & 28.6 & 29 \\
5. & Cairan rumen sapi & 30 & 30 & 29 & 30 & 29 & 29 & 29 \\
\hline
\end{tabular}

Hasil uji statistik Manova terhadap $\mathrm{pH}$ dan suhu menunjukkan nilai signifikansi sebesar $0.205>0.05$. Hal ini dapat disimpulkan bahwa secara statistik pe,mberian berbagai macam agen pendegradasi $\mathrm{Pb}$ berupa arang aktif, arang tongol jagung, PGPR dan cairan rumen sapi tidak berpengaruh secar signifikan terhadap $\mathrm{Ph}$ dan suhu bubur kertas pra pengomposan.

Berdasarkan hasil penelitian pada Tabel 1. diketahui bahwa tidak terjadi perubahan $\mathrm{pH}$ baik pada kontrol maupun perlakuan (penambahan arang aktif, arang tongol jagung, PGPR dan cairan rumen sapi) hal ini terjadi karena pada kontrol dan perlakuan berupa arang aktif dan arang tongkol jagung, diduga bakteri selulolitiknya sangat sedikit sehingga belum terjadi proses perombakan selulosa, hemiselulosa dan 
lignin pada kertas bekas bertinta. Sedangkan pada perlakuan penambahan PGPR dan cairan rumen sapi masih memiliki pH netral sampai hari ke-7 diduga karena keberadaan buffer fosfat yang ditambahkan pada proses inkubasi bakteri dalam PGPR dan cairan rumen sapi. Menurut Rahmawati (2017), pH antara 6 sampai 8 harus dipertahankan untuk menjaga metabolisme bakteri dalam hal ini bakteri yang terdapat dalam PGPR dan cairan rumen sapi tetap normal.

Fluktuasi suhu pada proses pengomposan menandakan terdapat proses perombakan materi organik dari bahan kompos menjadi unsur yang lebih sederhana oleh bakteri pendegradasi (Rahmawati, 2017). Berdasarkan Tabel 2. diketahui bahwa fluktuasi suhu pada kontrol dan perlakuan (penambahan arang aktif, arang tongol jagung, PGPR dan cairan rumen sapi) tidak terlampau besar hanya berkisar antara $27.8^{\circ} \mathrm{C}$ sampai $30{ }^{\circ} \mathrm{C}$. Hal ini dapat diduga karena proses perombakan belum terjadi secara optimal. Walaupun demikian jika diperhatikan Tabel 2. pada perlakuan penambahan PGPR dan cairan rumen sapi menunjukkan rerata suhu yang sedikit lebih tinggi daripada kontrol. Hal ini diduga karena pada PGPR dan cairan rumen sapi terdapat bakteri selulolitik sehingga proses perombakan sudah berlangsung meskipun aktivitasnya masih rendah.

Dalam upaya menurunkan beberapa kandungan kimia dalam kertas bekas bertinta seperti timbal $(\mathrm{Pb})$, Chlorin, pemutih dan lain-lain menggunakan bahan-bahan penyerap. Terdapat dua jenis bahan penyerap yaitu adsorben kimia dan biosorben. Adsorben kimia adalah material tak hidup yang digunakan untuk menyerap bahan kimia pencemar. Adsorben yang seringkali digunkan adalah arang aktif dan arang organik. Perbedaan dari arang aktif dan arang organik terletak pada keberadaan unsur karbon yang telah diaktifkan pada arang aktif. Pengaktifan unsur karbon pada arang aktif ini menyebabkan luas permukaannya bertambah besar sehingga kemampuan menyerap dan mengikat bahan pencemar lebih besar daripada arang organik. Sementara arang organic adalah arang yang terbentuk dari sisa pembakaran bahan organik yang tidak mengalami perlakuan apapun setelahnya. Walaupun kemampuannya tidak sebesar arang aktif arang organik memiliki potensi yang besar digunakan sebagai adsorben karena harganya yang murah dan keberadaannya yang melimpah. Salah satu arang organik yang memiliki potensi besar sebagai adsorben adalah arang limbah pertanian misalnya arang tongkol jagung (Kurniasari, 2010; Wardalia, 2016).

PGPR (Plant Growth Promoting Rhizobacteri) merupakan salah satu biosorben yang berasal dari bakteri yang lazim ditemukan dan hidup dalam sistem perakaran tanaman. Kelompok bakteri ini memiliki kemampuan membentuk lapisan biofilm untuk menyerap zat kimia pencemar. Selain itu PGPR sangat besar manfaatnya terhadap tanaman karena memiliki kemampuan untuk memobilisasi unusr hara tersedia bagi tanaman, sebagai penyedia fitohormon dan memiliki sifat antagonisme terhadap hama penyakit tanaman penganggu Kloepper et al., 1991 dalam Rahni, 2012; Meilani dan Bensoltane, 2016).

BIOLOGI SEL (VOL 10 NO 1 EDISI JAN-JUN 2021 ISSN 2252-858X/E-ISSN 2541-1225)PAGE 21 
Cairan rumen sapi yang diambil dari isi rumen sapi mengandung banyak mikroba baik berupa jamur maupun bakteri. Mikroba dalam rumen sapi tidak mempunyai kemampuan sebagai biosorben bahkan bakteri-bakteri tersebut sangat sensitif terhadap kandungan kimia. Namun demikian menurut Rahmawati, dkk. (2017) cairan rumen sapi yang memiliki kemampuan untuk mendegradasi kertas bekas dan menghasilkan unsur hara N, P, K yang telah sesuai dengan SNI 19-7030-2004 tentang kandungan unsur hara dan $\mathrm{Pb}$ pada kompos. Kemampuan cairan rumen sapi dalam mendegradasi kertas bekas bertinta disebabkan oleh keberadaan bakteri selulolitik yang merombak selulosa, hemiselulosa dan lignin dalam kertas menjadi unsur-unsur yang sederhana seperti N, P dan K (Hermawan dan Yulis, 2014; Rahmawati, dkk., 2017). Oleh karena itu cairan rumen sapi dapat digunakan sebagai starter pengomposan kertas bekas bertinta atau bahan lain yang mengandung selulosa.

Mekanisme arang aktif dalam menyerap kontaminan adalah dengan cara menyerap anion, kation dan molekul dalam bentuk senyawa organik, anorganik, larutan dan gas. Unsur karbon dalam arang aktif telah diaktifkan sehingga luas permukaannya bertambah sehingga meningkatkan kemampuan arang aktif dalam menarik kontaminan. Selanjutnya kontaminan diakumulasikan di dalam pori karbon aktif karena ukurannya lebih kecil (Syauqiah dkk., 2011). Mekanisme arang organik dalam menyerap kontaminan sama dengan arang aktif, yang membedakan adalah daya serap unsur karbonnya terhadap kontaminan. Karena unsur karbon dalam arang organik termasuk arang tongkol jagung belum diaktifkan maka luas permukaannya lebih kecil daripada arang aktif sehingga kemampuan dalam menyerap kontaminan juga demikian (Kurniasari, 2010). Sementara mekanisme PGPR dalam menyerap kontaminan adalah dengan cara membentuk biofilm yang merupakan kumpulan sel bakteri Alcaligenes sp. dan Pseudomonas sp. dalam PGPR yang melekat pada permukaan kontaminan dan diselimuti oleh larutan pekat berupa karbohidrat dari ekskresi bakteri-bakteri tersebut. Sehingga biofilm ini menurunkan toksisitas dari kontaminan (Patel et al., 2015; Meliani and Bensoltane, 2016).

\section{KESIMPULAN}

Pemberian arang aktif, arang tongkol jagung dan PGPR dapat dilakukan pada proses pra pengomposan kertas bekas bertinta dengan starter cairan rumen sapi tanpa menyebabkan terjadinya fluktuasi $\mathrm{pH}$ dan suhu. $\mathrm{pH}$ yang terukur pada proses pra pengomposan selama 7 hari baik pada kontrol dan perlakuan yaitu 7 , sedangkan suhunya antara $27.8{ }^{\circ} \mathrm{C}$ sampai $30^{\circ} \mathrm{C}$.

\section{SARAN}

Saran untuk penelitian selanjutnya Perlu dilakukan pengukuran kontaminan berupa chlorine, pemutih, timbal $(\mathrm{Pb})$ dan lain-lain untuk mengetahui efektivitas masing- 
masing adsorben terhadap penurunan kandungan kimia pada bahan baku kompos kertas bekas bertinta. Serta perlu dilakukan perhitungan jumlah dan identifikasi bakteri selulolitik yang terdapat dalam bahan baku kompos kertas bekas bertinta setelah ditambahkan adsorben bahan kimia kontaminan untuk mengetahui pengaruh penambahan adsorben terhadap keberadaan bakteri selulolitik pada kertas bekas bertinta sebagai unsur penting dalam proses degradasi limbah kertas bekas bertinta.

\section{UCAPAN TERIMAKASIH}

Penulis menyampaikan terimakasih kepada Lembaga Penelitian Universitas PGRI Ronggolawe Tuban yang telah menyediakan dana penelitian, Kepala Lab dan Laboran Biologi Universitas PGRI Ronggolawe Tuban serta semua pihak yang membantu.

\section{DAFTAR PUSTAKA}

Ahmad, A. R. dan Saftyaningsih, K. A. (2014). Pemanfaatan Hasil Pengolahan Limbah Kertas Pada Produk Tas dengan Teknik Paper Folding. ITB. Bandung

Hardiani, Henggar, Teddy Kardiansyah, dan Susi Sugesty. (2011). Bioremediasi Logam Timbal $(\mathrm{Pb})$ dalam Tanah terkontaminasi Limbah Sludge Industri Kertas Proses Deinking. Jurnal Selulosa, Vol. 1 No.1: 31-41.

Hermawan dan Yulis Aswar. (2014). Konversi Limbah Kertas Menjadi Etanol Menggunakan Kombinasi Enzim Selulose dan Selulobiase melalui Sakarifikasi dan Fermentasi Serentak. www.lontar.ui.ac.id. Diakses tanggal 8 Februari 2019.

Kurniasari, Laeli. (2010). Pemanfaatan Mikroorganisme dan Limbah pertanian sebagai Bahan Baku Biosorben Logam Berat. Momentum, Vol. 6. No. 2 : 5-8.

Meilani, Amina and Ahmed Bensoltane. (2016). Biofilm-Mediated Heavy Metals Bioremediation in PGPR Pseudomonas. Journal Bioremediat Biodegrad, Vol. 7 No.5

Patel, P. R. S. S Shaikh, and R. Z Sayyed. (2015). Dynamism of PGPR in Bioremediation and Plant Growth Promoting in Heavy Metal Contaminated Soil. Indian Journa of Experimental Biology. Vol. 54: 286-290.

Rahmawati, Annisa, Hesti Kurniahu, Sriwulan. (2017). Potensi pemanfaatan Cairan Rumen Sapi sebagai Starter Pengomposan Limbah Kertas Bertinta dan Limbah Organik Rumah Tangga. Laporan Penelitian. Tidak Dipublikasikan. Fakultas Matematika dan Ilmu Pengetahuan Alam Universitas PGRI Ronggolawe Tuban.

Rahni, Nini Mila. (2012). Efek Fitohormon PGPR terhadap Pertumbuhan Tanaman Jagung (Zea mays). Jurnal Agribisnis dan Pengembangan Wilayah, Vol. 3 (2).

Syauqiah, Isna Mayang Amalia, Hetty A. Kartini. (2011). Analisis Variasi Waktu dan Kecepatan Pengaduk pada Proses Adsorbsi Limbah Logam berat dengan Arang Aktif. Info Teknik, Vol. 2 No. 1: 11-20. 
Wardalia. (2016). Karakterisasi Pembuatan Adsorben dari Sekam Padi sebagai Pengadsorp Logam timbal pada Limbah Cair. Jurnal Integrasi Proses, Vol. 6. No. 2: $83-88$. 